\title{
Study of the oxidative degradation of industrial laundry effluent from jeans by chromatography
}

\author{
Estudo da degração oxidativa de efluente de lavanderia industrial de jeans por cromatografia \\ Estudio de la degradación oxidativa del efluente de ropa industrial de jeans por cromatografia
}

Received: 11/29/2021 | Reviewed: 12/04/2021 | Accept: 12/10/2021| Published: 12/18/2021

\author{
Rogério Ferreira da Silva \\ ORCID: https://orcid.org/0000-0002-0661-0307 \\ Universidade Federal de Pernambuco, Brazil \\ E-mail: rogerio.silva@belojardim.ifpe.edu.br \\ Gilson Lima da Silva \\ ORCID: https://orcid.org/0000-0003-2484-3590 \\ Universidade Federal de Pernambuco, Brazil \\ E-mail: gilsonlima28@ gmail.com \\ Victória Fernanda Alves Milanez \\ ORCID: https://orcid.org/0000-0001-6411-3352 \\ Universidade Federal de Pernambuco, Brazil \\ E-mail: victoriafamilanez@gmail.com \\ Gustavo José de Araújo Aguiar \\ ORCID: https://orcid.org/0000-0002-4727-2981 \\ Universidade Federal de Pernambuco, Brazil \\ E-mail: gustavo.aguiar@ufpe.br \\ Marcelo Fabrício Araújo \\ ORCID: https://orcid.org/0000-0002-2608-1211 \\ Universidade Federal de Pernambuco, Brazil \\ E-mail: marcelo.fabricio@ufpe.br \\ Ricardo Oliveira da Silva \\ ORCID: https://orcid.org/0000-0001-8090-7320 \\ Universidade Federal de Pernambuco, Brazil \\ E-mail: ros@ufpe.br
}

\begin{abstract}
Textile industries activities can positively affect a city's economy. However, those industries require a great deal of water and sheds high organic load into water bodies, causing a considerate environmental impact. As potential pollutant substances, the dye's presence in textile effluents are recalcitrant and can change the chemical and physical properties. It also resists conventional treatments. The treatment based on advanced oxidation processes presents to be efficient on dye's degradation, but it may generate secondary toxic compounds, therefore is necessary to use techniques to evaluate its toxicity after the treatment. This study evaluated a laundry effluent, both before and after the treatment using the photo - Fenton processes. Applying liquid chromatography, results have shown that the dye's degradation was higher than $90 \%$ and a COD decrease to $73 \%$.
\end{abstract}

Keywords: Dye degradation; Textile effluents; Advanced oxidation processes; Photo-Fenton.

\section{Resumo}

As atividades das indútrias têxteis podem afetar positivamente a economia de uma cidade. No entanto, essas industrias requerem uma grade quantidade de água e despejam uma grande carga orgânica em corpos d'água, causando um impacto ambiental considerável. Como substâncias potencialmente poluentes, a presença do corante em efluentes têxteis é recalcitrante e pode alterar as propriedades química e físicas. Também resiste aos tratamentos convencionais. $\mathrm{O}$ tratamento baseado em processos oxidativos avançadosapresenta-se eficiente na degradação do corante, mas pode gerar compostos tóxicos secundários, portanto é necessário o uso de técnicas para avaliar sua toxicidade após o tratamento. Este estudo avaliou um efluente de lavanderia, antes e depois do tratamento pelo processo foto-Fenton. Aplicado a cromatografia líquida, os resultados mostraram que a degradação do corante foi superior a $90 \%$ e a DQO diminui para $73 \%$.

Palavras-chave: Degradação de corantes; Efluentes têxteis; Processos de oxidação avançados; Foto-Fenton.

\section{Resumen}

Las actividades de las industrias textiles pueden afectar positivamente la economía de una ciudad. Sin embargo, esas industrias requieren una gran cantidad de agua y arrojan una alta carga orgánica a los cuerpos de agua, lo que causa un impacto ambiental considerable. Como sustancias potencialmente contaminantes, la presencia del tinte en los 
efluentes textiles son recalcitrantes y pueden cambiar las propiedades químicas y físicas. También resiste los tratamientos convencionales. El tratamiento basado en procesos de oxidación avanzada se presenta eficaz en la degradación del tinte, pero puede generar compuestos tóxicos secundarios, por lo que es necesario utilizar técnicas para evaluar su toxicidad después del tratamiento. Este estudio evaluó un efluente de lavandería, tanto antes como después del tratamiento mediante los procesos de foto - Fenton. Al aplicar la cromatografía líquida, los resultados han demostrado que la degradación del tinte fue superior al 90\% y una disminución de la DQO al $73 \%$.

Palabras clave: Degradación del tinte; Efluentes textiles; Procesos de oxidación avanzados; Foto-Fenton.

\section{Introduction}

The textile industry generates a large number of jobs. It embraces the natural and synthetic raw material production, fabric, trims, used on the garment processing up to final consumer product. Although it is considerate a very importantindustry sector to the country's economy, the textile industry has a high water consumption. In average, the fibets processing uses about $160 \mathrm{~m}^{3}$ of water per tons, to make the bleaching, the dyes process, mercerization and wash operations (Capar et al. 2008). Beyond the high water consumption, the effluents generated are potentially polluting and, if not treated properly, harms the environment. This fact requires reuse practices and efficient treatment ways (Mohan et al. 2007). Textile effluents have a high organic level, high in sodium and strong coloration originated by dissolved dyes unremoverd from fibers (Delee et al. 1998; Khaled et al. 2009; Ertuğrul, and Dönmez 2009; Bortoli et al., 2016). Coloreffluents absorb the sunlight and harm the photosynthesis process. Some of those are recalcitrant to conventional degradation (Peternel et al. 2006; Harrelkas et al. 2008; Revankar and Lele 2007; Dias et al., 2013; Dias et al., 2018). Dyes are difficult to remove from textile effluents due to its high water solubility and lowdegradation capacity (Meehan 2000; Balan and Monteiro 2001; Toh et al. 2003; Machulek et al. 2003). The azo dyes are resistant on aerobic conditions and can be toxic, if discharged without treatment, to plants and microorganisms (Gupte et al. 2013; Patil e Jadhav 2013). The substances reduction on effluents is based mainly on physiochemical methods, does not exist a universal treatment method, given that the textile effluents presents various and complex chemical structures in these compounds (Banat et al. 1996; Peralta-Zamora et al. 1999).

As an efficient alternative way to degrade recalcitrant compounds, advanced oxidation processes generates hydroxyl radical. It breaks the dyes chromophore group and converts azo dyes in carbon dioxide, an inorganic ion, and water (Moraes et al. 2000; Goi et al. 2010; Zapata et al. 2009, 2010; Lopez et al. 2004; Suresh and Raneshraja 2011; Shafieiyoun et al. 2012; Asaithambi et al. 2014).

The advanced oxidation processes can be classified as heterogeneous and homogeneous could be either with radiation or without it; among the homogeneous, the Fenton and photo-Fenton processes stand out. The Fenton reagent, obtained by hydrogen peroxide decomposition, catalyzed with ferrous ion $\left(\mathrm{Fe}^{2+}\right)$ in an acid medium. This decomposition forms hydroxyl radical $(\cdot \mathrm{OH})$ that reacts with pollutants, causing it to mineralize (Georgi et al. 2007; Nogueira et al. 2007, Ramos et al., 2013). The combination of Fenton reagent's with ultraviolet radiation results on the advanced oxidation processes known as photoFenton. This process basic feature comparing to the Fenton process is the increase in speed of the pollutants degradation due to the UV radiation presence. The degradation speed increases due to the photoreduction of $\mathrm{Fe}^{3+}$ to $\mathrm{Fe}^{2+}$ and the hydrogen peroxide photolysis producing more hydroxyl radical (García-Montaño et al. 2008). Applied to some moderate scale industrial practices the photo-Fenton reaction assists on the effluents and industrial residues treatment (Machulek et al. 2013).

Among all the techniques used to identify the compound's presence in effluents, the High-performance liquid chromatography (HPLC) stands out. This technique can recognize the presence of a specific substance and quantify it on a particular sample. This quantification is extremely important to evaluate the treatment process efficiency used to contaminants degradation (Vazquez-Roig et al. 2010). In contrast, the techniques used for toxicity evaluation are remarkably important. Due to the effluents complexity bearing pigments, the treatment becomes complex, since are found in its composition aromatic hydrocarbons and aliphatic deriving from dyes and organic solvents. These compounds remain on the industrial effluents 
resisting to the treatments and assigning them toxicity (Cavalcanti, 2009; Külzer and Rodrigues, 2016). This study evaluated the dyes degradation efficiency in textile effluents using the photo-Fenton process, and the liquid chromatography to quantify it.

\section{Methodology}

This work is based on experimental research on dye degradation by advanced oxidative process, considering qualitative and quantitative aspects of the reaction, finding support in studies such as those of Baydum et al. (2012), Tsui et al. (2001), Tayade et al. (2009) and Ahmed et al, (2016).

\section{Sample Preparation}

To prepare the aqueous solution that contains de-ionized water in a $1000 \mathrm{mg} . \mathrm{L}^{-1}$ concentration this study used the red dye drimaren CL-5B (Clariant $®)$ (Figure 1), due to the local demand and its stability. The laundry textile effluent was collected in a Polyethylene container, properly cleaned, and it was kept in temperature conditioning on $5^{\circ} \mathrm{C}$ until the moment it was subjected to photo-Fenton treatment.

Figure 1. Molecular structure of Drimaren Red dye CL-5B, molar mass: 1136.41 g.mol${ }^{-1}$.<smiles>CS(=O)(=O)OCCOS(=O)c1ccc(Nc2nc(Cl)nc(Nc3cc(S(=O)(=O)O)cc4cc([S+]([O])(=O)O[Na])c(N=Nc5ccc6c(S(C)(=O)=O)cccc6c5S(C)(=O)=O)c(O)c34)n2)cc1</smiles>

Source: Color Index Number CI: RR 241 (Khan et al., 2010).

It is perceived in the molecular structure, a sequence of double bonds, responsible for the color of the compound, this type of structure favors the attack by the hydroxyl radicals generated in the photo-Fenton reaction.

\section{Experimenting using the reactor}

The dye effluent samples were submitted to the photolysis process, peroxide and light, and the photo-Fenton process, in which the sample is exposed to the light, iron salts addition, and hydrogen peroxide. The artificial lights were used to run testes on the effluent sample through the bench reactor (Figure. 2) it has three fluorescent bulbs with 20 watts. 
Figure 2. Counter top with fluorescent lamp.

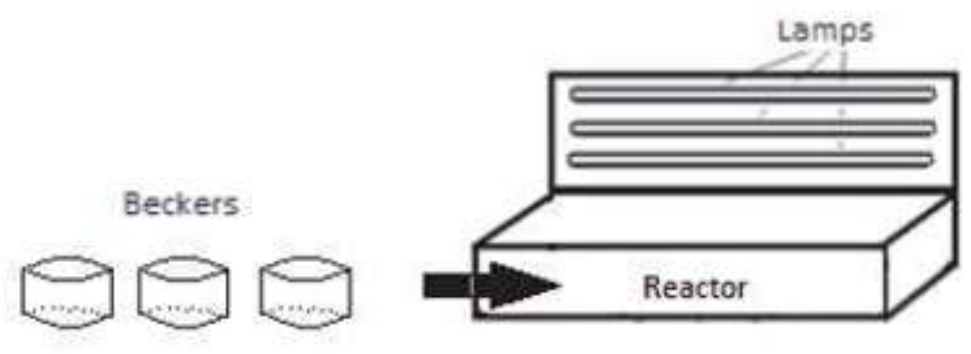

Source: Authors (2021).

The reactor has lamps that simulate solar irradiation and contributes to the development and performance of the reaction.

\section{Chromatographic analysis}

The chromatographic analysis began with the calibration curve preparation to quantify the dye degradation on the effluent sample. The data collected from the calibration curve are shown at table 1. Effluent samples were submitted to photoFenton process using artificial light, then, it was filtrated through a membrane with a pore diameter of $0,45 \mu \mathrm{m}$ to further analysis on the High Performance Liquid Chromatograph (Shimadzu) using UV-vis (SPD-20AV) detector. The experiment required an octadecylsilane (reversed-phase) column (150 mm x $2 \mathrm{~mm} \times 5 \mu \mathrm{m}$ ). As a mobile phase the proportion of $30 \%$ methanol and $70 \%$ of acidified water by acetic acid $1 \%$ was used, it also had $0,5 \mathrm{~mL} / \mathrm{min}$ flow, $10 \mu \mathrm{L}$ injection volume and wavelength detection of $545 \mathrm{~nm}$. The oven temperature was $40^{\circ} \mathrm{C}$. The calibration curve was prepared according to the following concentrations: $5 ; 10 ; 25 ; 50 ; 100 ; 250 ; 350$ e $500 \mathrm{mg} . \mathrm{L}^{-1}$. The dye's calibration curve was determined in triplicate. The quantification limits detection were calculated by $L D=3,3 \times(\mathrm{s} / \mathrm{S})$ e $L Q=10 \times(\mathrm{s} / \mathrm{S})$, in which $\mathrm{s}$ is the standard deviation from the lowest concentration and $S$ is the angular coefficient from the calibration curve (Khan et al. 2010; Ribani et al. 2004).

High Performance Liquid Chromatograph (HPLC) Shimadzu ® quantified the dye degradation. The samples were analyzed before and after the photo-Fenton treatment.

\section{Factorial planning and total organic carbon}

To evaluate the effect of the photo Fenton process a factorial planning $2^{3}$ was used, having a central point in triplicate to determine the best degradation condition of the model effluent contaminated by red dye drimaren CL-5B. Three variables were chosen to identify its influence on the dye degradation: reaction time while exposed to the sunlight, iron (mg) amount and the hydrogen peroxide $\left(\mathrm{H}_{2} \mathrm{O}_{2}\right)$ volume. Inside a beaker, it was added $25 \mathrm{~mL}$ of the model effluent, and the tests began following the planning matrix presented at table 1 . The same procedure was used to the real effluent. The hydrogen peroxide volume (Vetec ${ }^{\circledR}, 30 \%$ ), added to the sample, was based on total organic carbon (TOC) and the quantity of iron was based on the CONAMA 430/2011 procedure to the effluents, that is $15 \mathrm{mg} . \mathrm{L}^{-1}$. The effluent analyzed did not have endogenous iron, however ferrous sulfate heptahydrate $\left(\mathrm{FeSO}_{4} \cdot 7 \mathrm{H}_{2} \mathrm{O}\right)$ P.A ACS Dinamica was added. It should be pointed out that on table one only has the iron mass.

To calculate the hydrogen peroxide concentration, a hypothetical reaction was used from the carbon degradation on the dye by the hydroxyl radical, in which the molar proportion between the hydroxyl radical and carbon was 4:1, according to equation 6 (Velloso et al. 2009). 


$$
\mathrm{C}+4 \cdot \mathrm{OH} \rightarrow \mathrm{CO}_{2}+2 \mathrm{H}_{2} \mathrm{O}
$$

The radical originates from the reaction of peroxide with the ferrous ion. Therefore, equation 1 can be rewritten as shown in equation 2 .

$$
\mathrm{C}+2 \mathrm{H}_{2} \mathrm{O}_{2} \rightarrow \mathrm{CO}_{2}+\mathrm{H}_{2} \mathrm{O}
$$

Therefore, as one moll of carbon is chemically equivalent to two moles of hydrogen peroxide, the mass proportion between hydrogen peroxide and carbon is 5:3:1, respectively. The initial concentration of the dye was $1000 \mathrm{mg} . \mathrm{L}^{-1}$ with a COT equals to $202,6 \mathrm{mgC} . \mathrm{L}^{-1}$, the peroxide concentration was estimated to $202,6 \mathrm{x} 5,3=1148 \mathrm{mg} \mathrm{H}_{2} \mathrm{O}_{2} \cdot \mathrm{L}^{-1}=33$, $76 \mathrm{mM}$. It is known that the hydrogen peroxide density is $1,476 \mathrm{~g} \cdot \mathrm{mL}^{-1}$ at this concentration. The peroxide volume was calculated, resulting in $778 \mu \mathrm{L}$ that was added to the sample. To be the central point to the planning (Table 1) the volume equals to $750 \mu \mathrm{L}$ was chosen.

Table 1. Fatorial planning matrix $2^{3}$ with central point in triplicate to the dye degradation used in photo-Fenton process with sunlight.

\begin{tabular}{cccc}
\hline \multirow{2}{*}{ Variables } & \multicolumn{3}{c}{ Levels } \\
\cline { 2 - 4 } & -1 & 0 & +1 \\
\hline $\mathrm{t}(\mathrm{min})$ & 30 & 60 & 90 \\
\hline $\mathrm{H}_{2} \mathrm{O}_{2}(\mu \mathrm{L})$ & 600 & 750 & 900 \\
\hline $\mathrm{Fe}(\mathrm{mg})$ & 0,2 & 0,3 & 0,4 \\
\hline
\end{tabular}

Source: Authors (2021).

After each experiment sodium sulphite $\left(\mathrm{Na}_{2} \mathrm{SO}_{3}\right.$ ACS Dinamica) was added in stoechiometric amounts with the hydrogen peroxide to stop the reaction, due to the sodium sulphite capacity as reducing agent. Before the chromatographic analysis, the inhibitor was used to stop the reaction and a membrane of $0,45 \mu \mathrm{m}$ was used to filter.

\section{Results and Discussion}

The oxidative degradation tests were done using the model effluent and the real effluent. The model effluent was prepared using the red dye Drimaren. This dye is very popular among the jeans laundries; the real effluent was taken before the physicochemical treatment used by the jeans laundry.

\section{Study of the model effluent degradation}

The model effluent was characterized according to the values of $\mathrm{pH}$, concentration; chemical oxygen demand (COD) and total organic carbon (TOC) (Table 2)

Table 2. Model effluent characterization.

\begin{tabular}{cc}
\hline & Model Eflluent \\
\hline Concetration & $1,0 \times 10^{3} \mathrm{mg}_{\mathrm{L}} \mathrm{L}^{-1}$ \\
\hline $\mathrm{pH}$ & 3,3 \\
\hline Chemical Oxigen Demand & $1736,0 \mathrm{mgO}_{2} \cdot \mathrm{L}^{-1}$ \\
\hline Total Organic Carbon & $213,0 \mathrm{mgC} \cdot \mathrm{L}^{-1}$ \\
\hline
\end{tabular}

Source: Authors (2021). 
Three analytical curves were established to quantify the dye degradation, using a High Performance Liquid Chromatograph (Shimadzu (B). The coefficient of variation (CV) to the respective concentrations varied from 1 to $27 \%$. One of the analytical curves containing a concentration range of 5-500 mg. $\mathrm{L}^{-1}$, and its linear correlation coefficient $\left(\mathrm{R}^{2}\right)$ is represented at (Figure. 3)

Figure 3. Dye analytical curve.

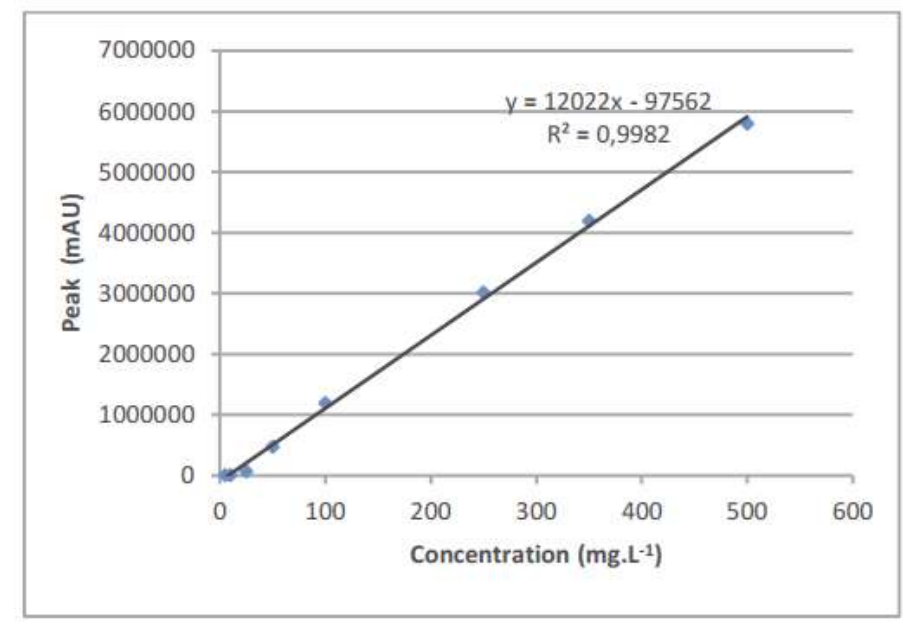

Source: Authors (2021).

The graph shows that there is a linear relationship between peak area and concentration, as observed by the curve and the coefficient and linear correlation.

\section{Photolytic degradation}

The qualitative result of the model effluent degradation by photolysis using a bench reactor (figure 2), demonstrated that did not occur any color alteration, therefore the photolysis can be ruled out as a solution. To the majority of dyes, the photolysis process can be very difficult or very slowly, due to the compounds resistance to degradation by UV (Baydum et al. 2012). A study about the photolysis of the red acid 8 dye, on the concentrations of $1.10^{-4}$ mol.L $\mathrm{L}^{-1}, 5.10^{-5} \mathrm{~mol} . \mathrm{L}^{-1} \mathrm{e} 1.10^{-5}$ mol.L $\mathrm{L}^{-1}$, showed that the dye degradation reduced with the increase of the concentration (Tsui et al. 2001), meanwhile in another study showed the difficult to degrade the methyleneblue by photolysis using a bench reactor (Tayade et al. 2009). It is possible to find in the literature that thedegradation of methylene blue was ineffective using the photolysis process during one hour, even on the presence of different catalysis, reaching only $0,40 \%$ of discoloration efficiency, to visible radiation (Ahmedet al, 2016). Lastly, it should be pointed out that, in this study the dye concentration was a hundred times bigger than the one used on the referred study, which may justify the photolysis inefficiency. Once observed that the photolysis did not degraded the model effluent, the photo-Fenton process was chosen.

\section{Photo-Fenton degradation}

The degradation of the model effluent by photo-Fenton process was quantified by chromatography, as shown on (Table 3). The experiments carried out without iron addition showed that the degradation process did not occur. The addition of iron salts or iron oxides increase the photo-Fenton reaction efficiency, due to its power as catalyzer increasing the reaction speed (Muruganandham et al. 2006). Thereupon the tests, the quantity of residual peroxide was measured using colorimetric tape (Test Peróxidos Merck -1.1000L0001), that changes the color accordingly to the amount of peroxide. 
Table 3. Results of the degradation and mineralization of model effluent after photo-fenton process with artificial light.

\begin{tabular}{cccccc}
\hline Sample & H2O2 & Iron & Time & Degradation & TOC \\
\hline 1 & $(\boldsymbol{\mu L})$ & $(\mathbf{m g})$ & $(\mathbf{m i n})$. & $(\boldsymbol{\%})$ & $(\%)$ \\
\hline 2 & 900 & 0,4 & 90 & 99,2 & 73,97 \\
3 & 600 & 0,4 & 90 & 99,0 & 72,85 \\
4 & 900 & 0,2 & 90 & 99,2 & 72,27 \\
5 & 600 & 0,2 & 90 & 99,1 & 51,63 \\
6 & 900 & 0,4 & 30 & 99,0 & 41,07 \\
7 & 600 & 0,4 & 30 & 99,1 & 51,68 \\
8 & 900 & 0,2 & 30 & 99,1 & 59,65 \\
9 & 600 & 0,2 & 30 & 99,1 & $68,61 \pm 1,29$ \\
9 & 750 & 0,3 & 60 & $99,1 \pm 0,00$ & $67,54 \pm 1,29$ \\
9 & 750 & 0,3 & 60 & $99,1 \pm 0,00$ & $66,33 \pm 1,29$ \\
\hline
\end{tabular}

Source: Authors.

The results obtained by the degradation and mineralization of the model effluent were analyzes by Statistica program and examined using Pareto Graph. The table shows that in tests that lasted longer, the model effluent mineralization was higher, indicating that the reactional time interfere directly on the degradation process, because it allows a great activity of hydroxyl radicals. Factors, peroxide, iron and time are not statistical significant on a $95 \%$ confidence level, however the interaction between factors, peroxide and time is significant at a 95\% confidence level (Figure. 4). The peroxide concentration associated to time influence directly on the dye degradation, as the hydroxyl radicals are originates from the homolysis of the hydrogen peroxide molecule and it is responsible for the degradation and act accordingly to the reactional time proposed. This information is supported by other authors that also confirmed that the increase of time is associated to the increase of the reagents concentration responsible for oxidation, which provokes an increase on the RB5 degradation, a textile dye (Dias et al., 2018; Giraldo et al, 2005). 
Research, Society and Development, v. 10, n. 16, e550101624044, 2021

(CC BY 4.0) | ISSN 2525-3409 | DOI: http://dx.doi.org/10.33448/rsd-v10i16.24044

Figure 4. Analysis of the effects of factors on dye degradation after photo-Fenton.

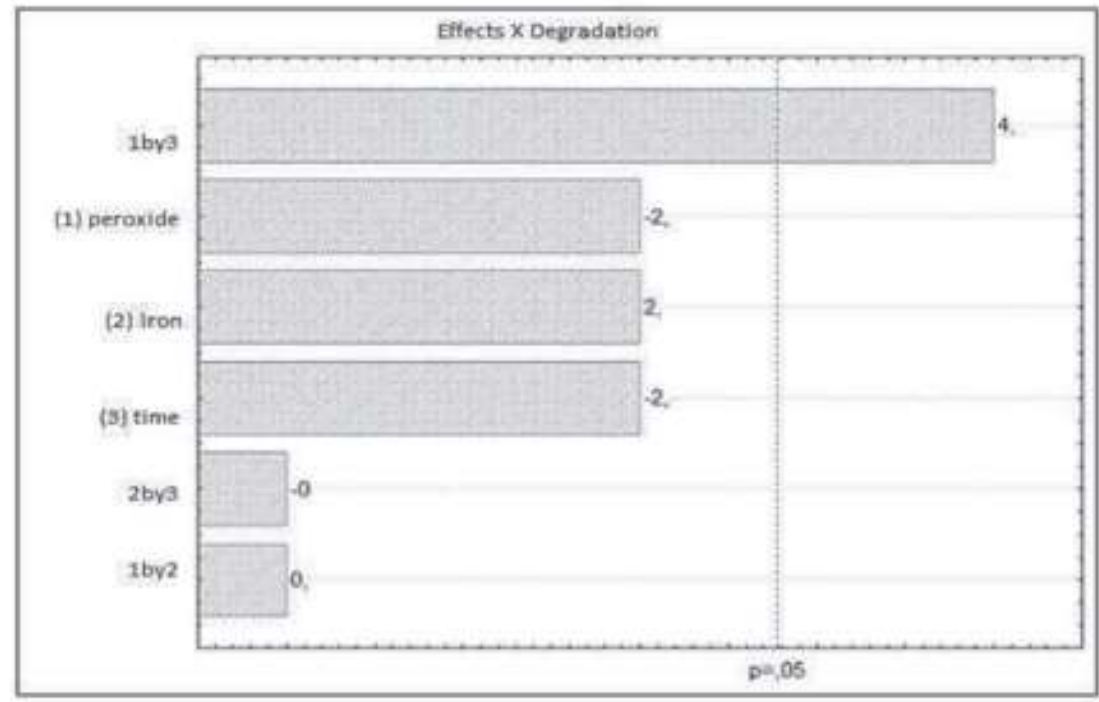

Source: Authors (2021).

The dye mineralization on the model effluent, measured based on total organic carbon, the time influenced the most after the photo-Fenton process (Figure 5), which is coherent, because the longer the time, the more radicals promote oxidation of the compound.

Figure 5. Pareto plot for the analysis of the factors effects on the dye mineralization after photo-Fenton treatment.

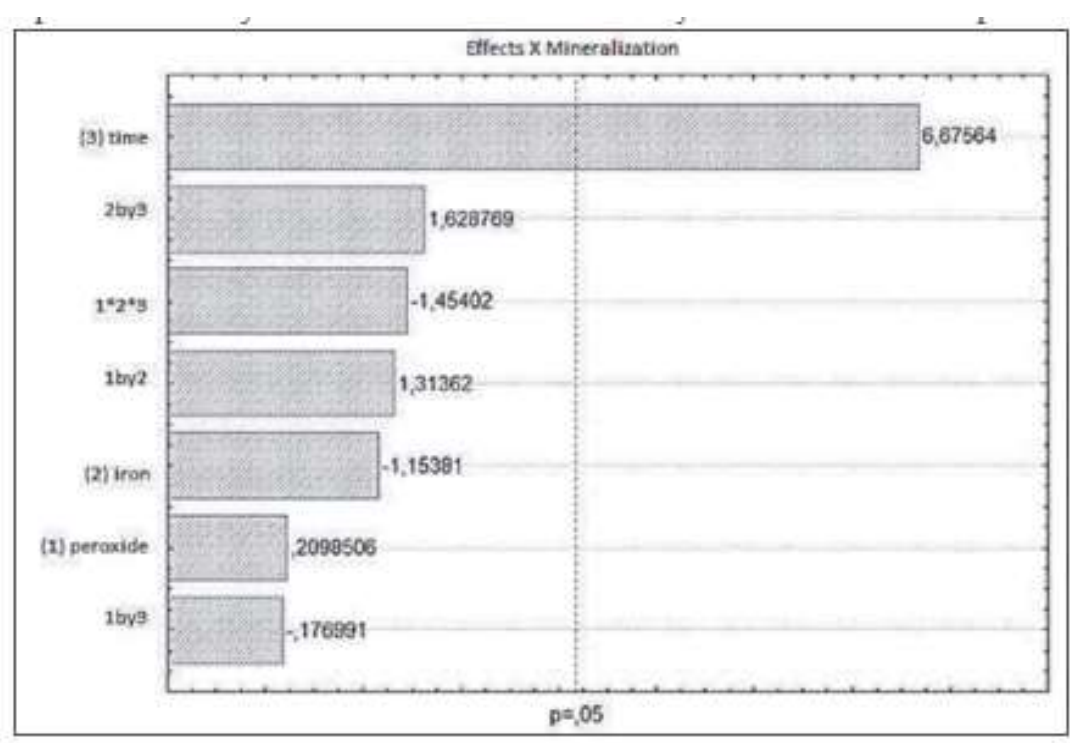

Source: Authors (2021).

The graphic showed that the time's effect is very significant at a $95 \%$ confidence level compared with the dye mineralization after photo-Fenton treatment. The others factors are below this confidence level. Thus, the amount of time it is important to the degradation and mineralization. 


\section{Analysis of chemical oxygen demand after photo-fenton treatment}

The chemical oxygen demand reduction was obtained on experimental conditions that mineralized the most the model effluent. This study was able to make a reduction of $73,34 \%$ to COD at $0,94 \mathrm{mM}$ red dye drimaren CL-5B concentration in 90 minutes of experiment (Table 4).

Table 4. COD result for model effluent.

\begin{tabular}{|c|c|c|}
\hline Model Effluent & COD (MG OF O2.L $\left.\mathrm{L}^{-1}\right)$ & Reduction (\%) \\
\hline Not treated & 1763.4 & \\
\hline Treated & 470.00 & 73.74 \\
\hline
\end{tabular}

Source: Authors (2021).

A study with the azocorante red mordant 73 showed that for degradation with the photo-Fenton process the COD reduction was $85 \%$ in 180 minutes duration of experiment for a dye concentration of $0.1 \mathrm{mM}$ (Muruganandham et al., 2006; Silva et al., 2017). In other study, the reseachers degradating in $240 \mathrm{~min}$ the dye reactive yellow 145 with a concetration of 50 ppm, they obtained a COD of 86,7\% (Patel et al., 2019). The COD reduction percentage obtained by this study was lower and a concentration approximately nine times higher, however still had a difference of $10 \%$ in relation to the cited works.

\section{Chromatographic study of before and after photo-fenton model effluent degradation}

The dye degradation was quantified by chromatography. The retention time observed for it was 1.82 minutes. The chromatogram for the concentration of $100 \mathrm{mg} . \mathrm{L}^{-1}$ of the model effluent is presented in (Figure 6). The maximum intensity peak characterizes the dye in a concentrated solution of $100 \mathrm{mg} \cdot \mathrm{L}^{-1}$ before the treatment, the other chromatograms show the behavior of this maximum peak after the photo-Fenton treatment.

Figure 6. Chromatogram of the red dye drimaren CL-5B at the concentration of $100 \mathrm{mg} . \mathrm{L}^{-1}$

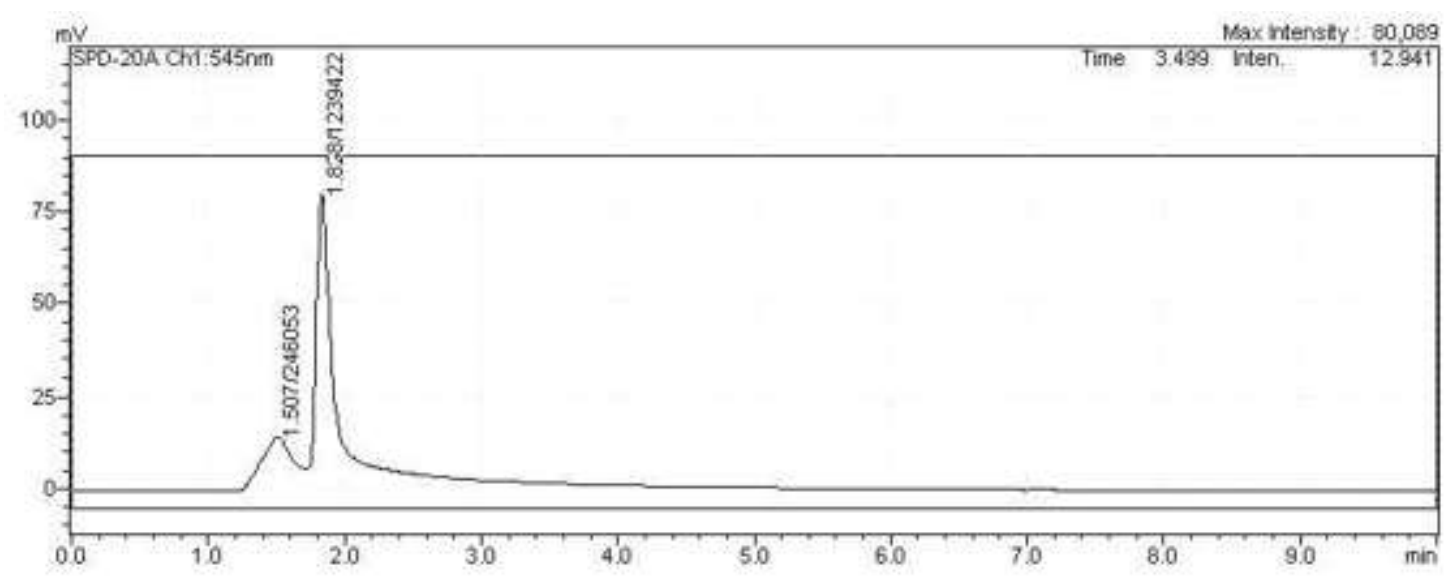

Source: Authors (2021).

After treatment with the photo-Fenton process using artificial light, the dye peak disappears in the time of 1.82 minutes, which indicates the dye degradation by the process studied. The peak disappearance at the retention time indicates that the treatment application promotes the breakdown of the dye structure and prevents the radiation absorption at the same wavelength. The small peak that is present before and after the treatment is an indication of impurity in the sample since a commercial dye 
does not have analytical purity.

Figure 7. Chromatogram of the red dye drimaren CL-5B at the concentration of $1000 \mathrm{ppm}$ after treatment with photo-Fenton process after $30 \mathrm{~min}$. addition of $600 \mu \mathrm{L}$ and $0.4 \mathrm{mg}$ of iron.

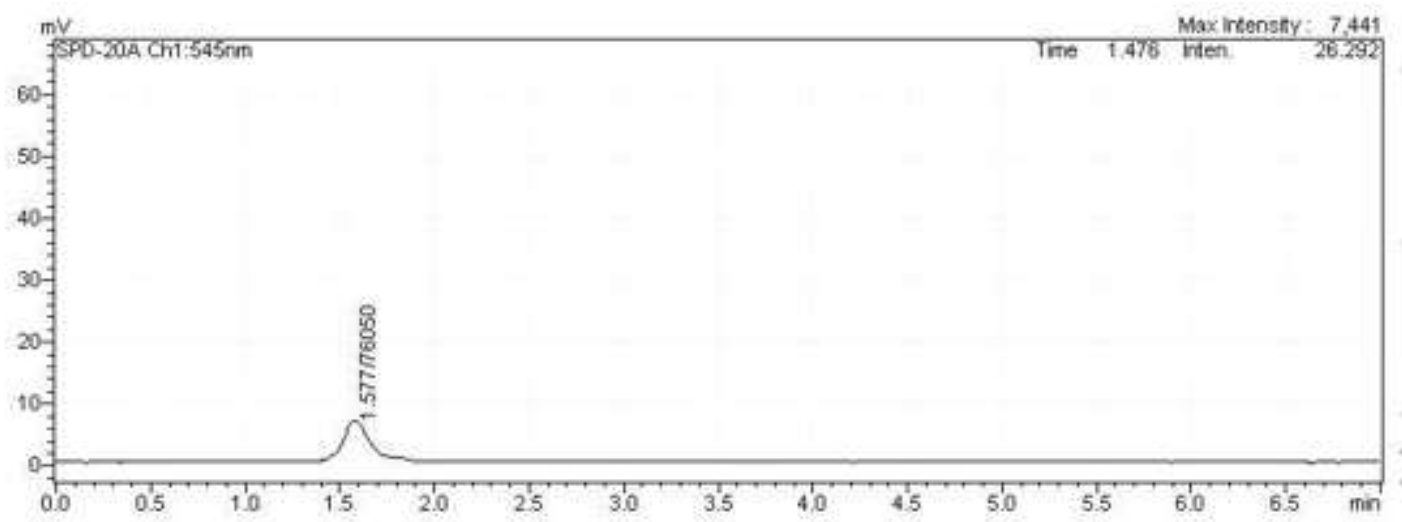

Source: Authors (2021).

The chromatograms, in which the model effluent was subjected to reaction only with peroxide and light and without the addition of iron, the peak does not disappear (Figure 8 and 9).

Figure 8. Red dye drimaren CL-5B chromatogram at $1000 \mathrm{ppm}$ concentration after treatment with H2O2/UV.

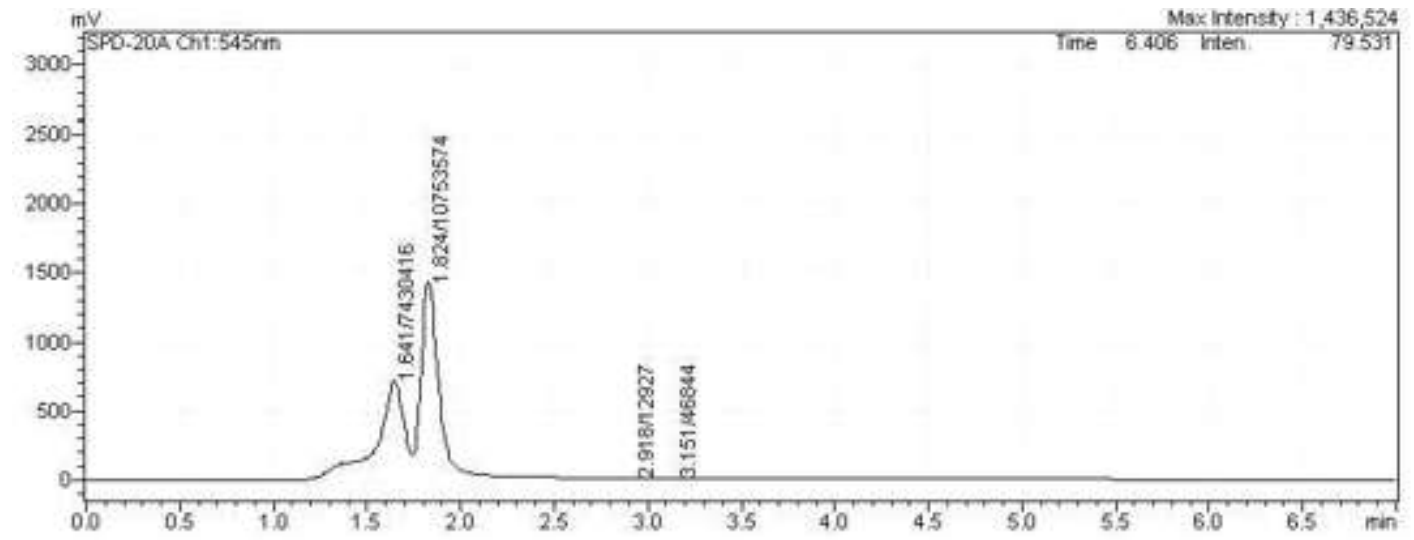

Source: Authors (2021).

The treatment with peroxide and light is inefficient in the removal of color from the model effluent, because iron is an important factor and acts as a catalyst (Elmorsi et al., 2010). 
Figure 9. Repetition of experiment of the figure 8 with $\mathrm{H}_{2} \mathrm{O}_{2} / \mathrm{UV}$.

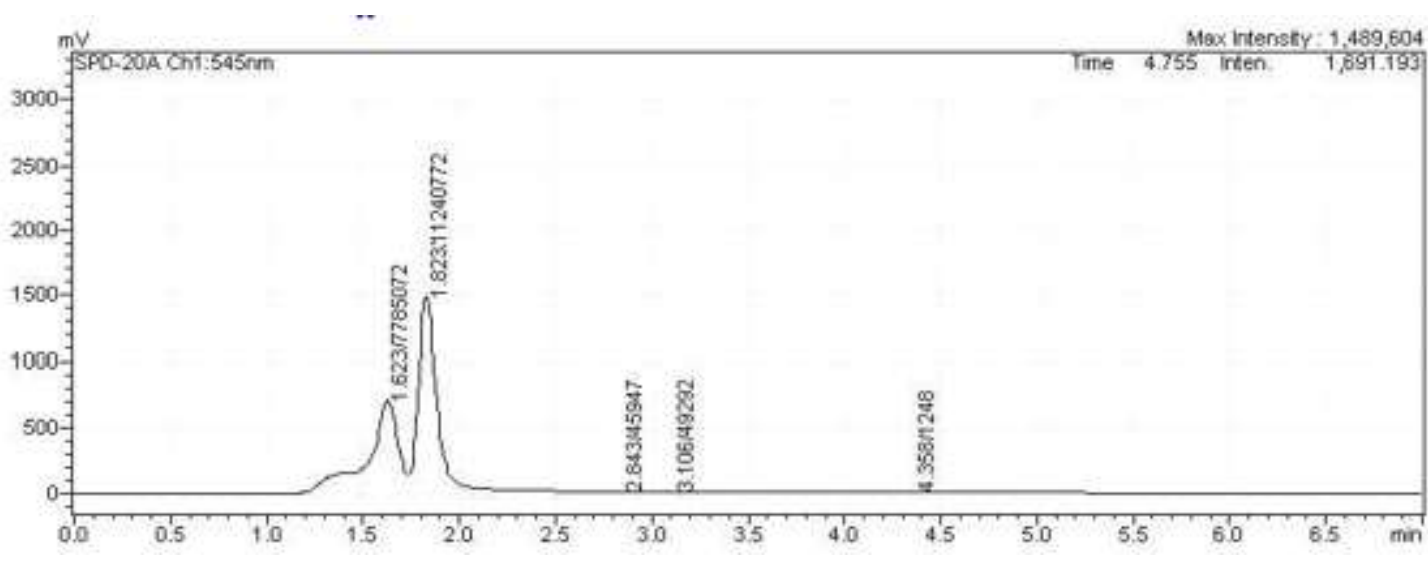

Source: Authors (2021).

This chromatogram is a repetition of the dye degradation experiment with a concentration of $1000 \mathrm{ppm}$, showing that degradation does not occur, using only $\mathrm{H} 2 \mathrm{O} 2 / \mathrm{UV}$, verified by the presence of the peak.

\section{Conclusion}

Therefore, can be concluded that the photo-Fenton process degraded the model effluent and the real effluent. Chromatographic analysis indicates that the total peak disappearance in the chromatogram after treatment shows that the dye degradation occurred in the model effluent. The degradation of the real effluent was satisfactory with a mineralization around $70 \%$, COD reduction around $70 \%$, removal of up to $98.46 \%$ of turbidity and $80.60 \%$ of color. Given the results obtained, it is intended to analyze the degradation of other dyes in liquid and solid matrices.

\section{Acknowledgments}

The authors thank the Advanced Environmental Management Group of the Federal University of Pernambuco, the Academic Center of the Agreste - Caruaru-PE and Postgraduate Program in Civil and Environmental Engineering for all the support and encouragement of research development. The PROPEG and CAPES for the incentive. This work was carried out with support of CAPES - financing code 001.

\section{References}

Ahmed, Y., Yaakob, Z., \& Akhtar, P. (2016). Degradation and mineralization of methylene blue using a heterogeneous photo-Fenton catalyst under visible and solar light irradiation. Catalysis Science \& Technology, 6(4), 1222-1232.

Asaithambi, P., Saravanathamizhan, R., \& Matheswaran, M. (2015). Comparison of treatment and energy efficiency of advanced oxidation processes for the distillery wastewater. International journal of environmental science and technology, 12(7), 2213-2220.

Balan, D. S., \& Monteiro, R. T. (2001). Decolorization of textile indigo dye by ligninolytic fungi. Journal of Biotechnology, 89(2-3), $141-145$.

Banat, I. M., Nigam, P., Singh, D., \& Marchant, R. (1996). Microbial decolorization of textile-dyecontaining effluents: a review. Bioresource technology, 58(3), 217-227.

Baydum, V. P., Dantas, R. F., Teixeira, A., Pacheco, J. G., \& Silva, V. L. (2012). Pre-treatment of propranolol effluent by advanced oxidation processes. Afinidad, 69(559).

Bortoti, A. A., da Rosa, M. F., Bariccatti, R. A., \& Lobo, V. D. S. (2016). Evaluation of the photo-Fenton process on discoloration of a commercial textile dye. Semina: Ciências Exatas e Tecnológicas (Londrina), 37(1), 81-90.

Capar, G., Yilmaz, L. E. V. E. N. T., \& Yetis, U. (2008). A membrane-based co-treatment strategy for the recovery of print-and beck-dyeing textile effluents. Journal of hazardous materials, 152(1), 316-323. 
Cavalcanti, J. E. W. A. (2009). Manual de tratamento de efluentes industriais. Engenho, 2423-2428.

Delee, W., O'Neill, C., Hawkes, F. R., \& Pinheiro, H. M. (1998). Anaerobic treatment of textile effluents: a review. Journal of Chemical Technology \& Biotechnology: International Research in Process, Environmental AND Clean Technology, 73(4), 323-335.

Dias, F. F. S., Chiavone-Filho, O., Lira, R. M., Carvalho, F. O., \& Pacheco, J. G. (2013). Degradação de corante Reative Black 5 via processo foto-Fenton com modelagem e otimização utilizando RNA. Scientia Plena, 9(10).

Dias, F. F., Silva, P. B. V., de Santos, A. F., Andrade, J. G. P., \& Albuquerque, I. L. T. (2018). Treatment of textile effluent through advanced oxidative process (H2O2/TiO2/UV). Revista Geama, 4(3), 4-9.

Elmorsi, T. M., Riyad, Y. M., Mohamed, Z. H., \& Abd El Bary, H. M. (2010). Decolorization of Mordant red 73 azo dye in water using H2O2/UV and photoFenton treatment. Journal of Hazardous Materials, 174(1-3), 352-358.

Ertuğrul, S., San, N. O., \& Dönmez, G. (2009). Treatment of dye (Remazol Blue) and heavy metals using yeast cells with the purpose of managing polluted textile wastewaters. Ecological Engineering, 35(1), 128-134.

García-Montaño, J., Domènech, X., García-Hortal, J. A., Torrades, F., \& Peral, J. (2008). The testing of several biological and chemical coupled treatments for Cibacron Red FN-R azo dye removal. Journal of hazardous materials, 154(1-3), 484-490.

Georgi A, Schierz A, Trommler U, Horwitz CP, Collins TJ, Kopinke FD (2007) Applied Catalisys B. Environmental,72:26-36.

Giraldo, L. F. G., Ángel, M. L. H., Mesa, G. A. P., Restrepo, A. R., \& Palacio, J. A. S. (2005). Degradación de aguas residuales de la industria textil por medio de fotocatálisis. Revista Lasallista de investigación, 2(1), 15-18.

Goi, A., Veressinina, Y., \& Trapido, M. (2010). Fenton process for landfill leachate treatment: evaluation of biodegradability and toxicity. Journal of Environmental Engineering, 136(1), 46-53.

Gupte, S., Keharia, H., \& Gupte, A. (2013). Toxicity analysis of azo Red BS and Methyl Red dye solutions on earthworm (Pheretima phosthuma), microorganisms, and plants. Desalination and Water Treatment, 51(22-24), 4556-4565.

Harrelkas, F., Paulo, A., Alves, M. M., El Khadir, L., Zahraa, O., Pons, M. N., \& Van Der Zee, F. P. (2008). Photocatalytic and combined anaerobicphotocatalytic treatment of textile dyes. Chemosphere, 72(11), 1816-1822.

Khaled, A., El Nemr, A., El-Sikaily, A., \& Abdelwahab, O. (2009). Treatment of artificial textile dye effluent containing Direct Yellow 12 by orange peel carbon. Desalination, 238(1-3), 210-232.

Khan, H., Ahmad, N., Yasar, A., \& Shahid, R. (2010). Advanced Oxidative Decolorization of Red Cl-5B: Effects of Dye Concentration, Process Optimization and Reaction Kinetics. Polish journal of environmental studies, 19(1).

Külzer, B. N., \& Rodrigues, C. O. (2016) Generation and Physicochemical Treatment Processes of Wastewater Containing Pigment. Holos Environment, 16:58-69.

Lopez, A., Pagano, M., Volpe, A., \& Di Pinto, A. C. (2004) Fento's pre-treatment of mature landfill leachate. Chemosphere54:1005 1010.

Machulek, J. R. A., et al. (2003) Comparative studies of fungal degradation of single or mixed bioaccessible reactive azo dyes. Chemosphere, 52:967-973.

Meehan, C., Banat, I. M., McMullan, G., Nigam, P., Smyth, F., \& Marchant, R. (2000). Decolorization of Remazol Black-B using a thermotolerant yeast, Kluyveromyces marxianus IMB3. Environment international, 26(1-2), 75-79.

Mohan, N., Balasubramanian, N., \& Basha, C. A. (2007). Electrochemical oxidation of textile wastewater and its reuse. Journal of hazardous materials, 147(1-2), 644-651.

Moraes, S. G., Freire, R. S., \& Duran, N. (2000). Degradation and toxicity reduction of textile effluent by combined photocatalytic and ozonation processes. Chemosphere, 40(4), 369-373.

Machulek Jr, A., Oliveira, S. C., Osugi, M. E., Ferreira, V. S., Quina, F. H., Dantas, R. F., \& Nogueira, J. A. (2013). Application of different advanced oxidation processes for the degradation of organic pollutants. In Organic pollutants-Monitoring, risk and treatment (Vol. 1, pp. 141-166). InTech.

Muruganandham, M., \& Swaminathan, M. (2004). Solar photocatalytic degradation of a reactive azo dye in TiO2-suspension. Solar Energy Materials and Solar Cells, 81(4), 439-457.

Nogueira, R. F. B., Trovó, A. G., Silva, M. R. A., \& Villa, R. D. (2007). Fundamentals and environmental applications of the FENTON and PHOTO-FENTON processes. New Chemistry,30:400-408.

Palmieri, G., Cennamo, G., \& Sannia, G. (2005). Remazol Brilliant Blue R decolourisation by the fungus Pleurotus ostreatus and its oxidative enzymatic system. Enzyme and Microbial Technology, 36(1), 17-24.

Patil, A. V., \& Jadhav, J. P. (2013). Evaluation of phytoremediation potential of Tagetes patula L. for the degradation of textile dye Reactive Blue 160 and assessment of the toxicity of degraded metabolites by cytogenotoxicity. Chemosphere, 92(2), 225-232.

Patel, S. K., Patel, S. G., \& Patel, G. V. (2019). Degradation of Reactive Dye in Aqueous Solution by Fenton, Photo-Fenton Process and Combination Process with Activated Charcoal and TiO 2. Proceedings of the National Academy of Sciences, India Section A: Physical Sciences, 1-13.

Peralta-Zamora, P., Kunz, A., de Moraes, S. G., Pelegrini, R., de Campos Moleiro, P., Reyes, J., \& Duran, N. (1999). Degradation of reactive dyes I. A comparative study of ozonation, enzymatic and photochemical processes. Chemosphere, 38(4), 835-852. 
Research, Society and Development, v. 10, n. 16, e550101624044, 2021

(CC BY 4.0) | ISSN 2525-3409 | DOI: http://dx.doi.org/10.33448/rsd-v10i16.24044

Peternel, I., Koprivanac, N., \& Kusic, H. (2006). UV-based processes for reactive azo dye mineralization. Water research, 40(3), 525-532.

Revankar, M. S., \& Lele, S. S. (2007). Synthetic dye decolorization by white rot fungus, Ganoderma sp. WR-1. Bioresource Technology, 98(4), 775-780.

Ribani, M., Bottoli, C. B. G., Collins, C. H., Jardim, I. C. S. F., \& Melo, L. F. C. (2004). Validação em métodos cromatográficos e eletroforéticos. Química nova, 27(5), 771-780.

Shafieiyoun, S., Ebadi, T., \& Nikazar, M. (2012). Treatment of landfill leachate by Fenton process with nano sized zero valent iron particles.

Silva, R. F., Silva, G. L., \& Silva, R. O. (2017) Photo-Fenton Process: Degradation of Drimaren Red CL-5B Dye and Ecotoxicity Study of Jeans Laundry Effluent. Journal of Environmental Science and Pollution Research, 3, 219-224

Suresh, S., \& Rameshraja, D. (2011). Treatment of tannery wastewater by various oxidation and combined processes: review. Int. J. Environment Res, 5(2), 349-360.

Tayade, R. J., Natarajan, T. S., \& Bajaj, H. C. (2009). Photocatalytic degradation of methylene blue dye using ultraviolet light emitting diodes. Industrial \& Engineering Chemistry Research, 48(23), 10262-10267.

Toh, Y. C., Yen, J. J. L., Obbard, J. P., \& Ting, Y. P. (2003). Decolourisation of azo dyes by white-rot fungi (WRF) isolated in Singapore. Enzyme and Microbial Technology, 33(5), 569-575.

Tsui, S. M., Chu, W., Fung, P. C., \& Sin, K. M. (2001). Removal of hydrophobic dyestuff from dyeing wastewater by photo-sensitization process. Water Science and Technology, 43(2), 305-312.

Vazquez-Roig, P., Segarra, R., Blasco, C., Andreu, V., \& Picó, Y. (2010). Determination of pharmaceuticals in soils and sediments by pressurized liquid extraction and liquid chromatography tandem mass spectrometry. Journal of Chromatography A, 1217(16), 2471-2483.

Velloso, F. T., Ferraz, R. S., Lira, A. A. M., de Santana, D. P., \& Santos-Magalhães, N. S. (2009). Development and validation of an analytical method using HPLC-UV for the quantification of retinoic acid in alginate and chitosan microcapsules. Brazilian Journal of Pharmaceutical Sciences, 45(1), 177-183.

Zapata, A., Velegraki, T., Sánchez-Pérez, J. A., Mantzavinos, D., Maldonado, M. I., \& Malato, S. (2009). Solar photo-Fenton treatment of pesticides in water: effect of iron concentration on degradation and assessment of ecotoxicity and biodegradability. Applied Catalysis B: Environmental, 88(3-4), 448-454.

Zapata, A., Oller, I., Sirtori, C., Rodríguez, A., Sánchez-Pérez, J. A., López, A., \& Malato, S. (2010). Decontamination of industrial wastewater containing pesticides by combining large-scale homogeneous solar photocatalysis and biological treatment. Chemical Engineering Journal, 160(2), 447-456. 